\title{
ON THE EVE OF URBANIZATION: BAYESIAN MODEL DATING FOR MEDIEVAL TURKU
}

\author{
M Oinonen ${ }^{1,2,3} \bullet$ E Hilasvuori $^{1,4} \bullet$ H Mehtonen $^{1} \cdot \mathrm{K}_{\text {Uotila }}^{5,6} \bullet$ P Zetterberg $^{6}$ \\ ABSTRACT. The era of early urbanization in Finland coincides with large variations in the atmospheric radiocarbon con- \\ centration around the 13th-14th centuries $\mathrm{AD}$. Therefore, the uncertainties of an individual ${ }^{14} \mathrm{C}$ date are too large to support \\ studies of this time period effectively. In this work, we have employ tree-ring wiggle-matching methodology and used Baye- \\ sian modeling of dates to account for stratigraphical a priori information within Aboa Vetus Museum, Turku, Finland. The \\ wiggle-match method helps significantly to overcome the calibration-curve-induced challenges within ${ }^{14} \mathrm{C}$ dating. The results \\ of the dating model agree with the typological dates of the archaeological finds and illustrate a gradual evolution of urban- \\ ization in one of the oldest cities in Finland.
}

\section{INTRODUCTION}

The era of the early urbanization of Turku (Hiekkanen 2002; Taavitsainen and Uotila 2009; Seppänen 2011) and also generally in Finland coincides with large variations in the atmospheric radiocarbon concentration at around the 13th-14th century AD. The changes in concentration and thus in the calibration curve (Reimer et al. 2009) are propagated into the calendar year probability distribution. Therefore, an individual ${ }^{14} \mathrm{C}$ date yields typically to a century-wide calendar year probability distribution (Figure 1) that is too broad to support the fragmentary historical data in studies of the eve of urbanization. A recipe to overcome these challenges has been pioneered by Pearson (1986) by describing a curve-fitting or "wiggle-matching" technique to take advantage of the time separation of samples with a known deposition rate. The method was later developed into a Bayesian framework by Christen and Litton (1995) and implemented in sophisticated analysis software by Bronk Ramsey et al. (2001).

One of the most visible manifestations of early urbanization in Finland is the Aboa Vetus Museum (http://www.aboavetusarsnova.fi/en) on the eastern bank of the Aura River in Turku. Aboa Vetus is a genuine in situ museum in the city center. A large underground area of ruins of Medieval buildings was discovered below the 1928-built Villa von Rettig in Turku during the 1990s. In excavations in 1992-1995 and 2005-2010, a whole Medieval city block was unearthed and presently the museum contains 5-6 Medieval stone and brick houses, and the area is crossed by 2 Medieval roads (Figure 2). This location in between the 13th century cathedral of Turku and the Dominican Convent emphasizes the role of the site in the heart of ancient Turku (e.g. Pihlman 2010; Sartes 2003; Seppänen 2011; Taavitsainen and Uotila 2009; Uotila 2009 and references therein). The museum exhibits several house yards, one of which was subjected to archaeological excavations in 2009-2010.

In this work, we scrutinize the Bayesian wiggle-matching methodology and model dating using stratigraphical a priori information based on excavations at the Aboa Vetus Museum to overcome the ${ }^{14} \mathrm{C}$ dating challenges within the era. Specifically, the approach is utilized for a dendrochronologically dated sample from Aboa Vetus and for material found in the 2009-2010 archaeological

\footnotetext{
${ }^{1}$ Finnish Museum of Natural History - LUOMUS, University of Helsinki, Finland.

${ }^{2}$ Corresponding author. Email: markku.j.oinonen@helsinki.fi.

${ }^{3}$ Docent, University of Turku, Finland.

${ }^{4}$ Finnish Environmental Institute, Helsinki, Finland.

${ }^{5}$ Muuritutkimus ky, Kaarina, Finland.

${ }^{6}$ Laboratory of Dendrochronology, University of Eastern Finland, Finland.
} 


\section{Oinonen et al.}

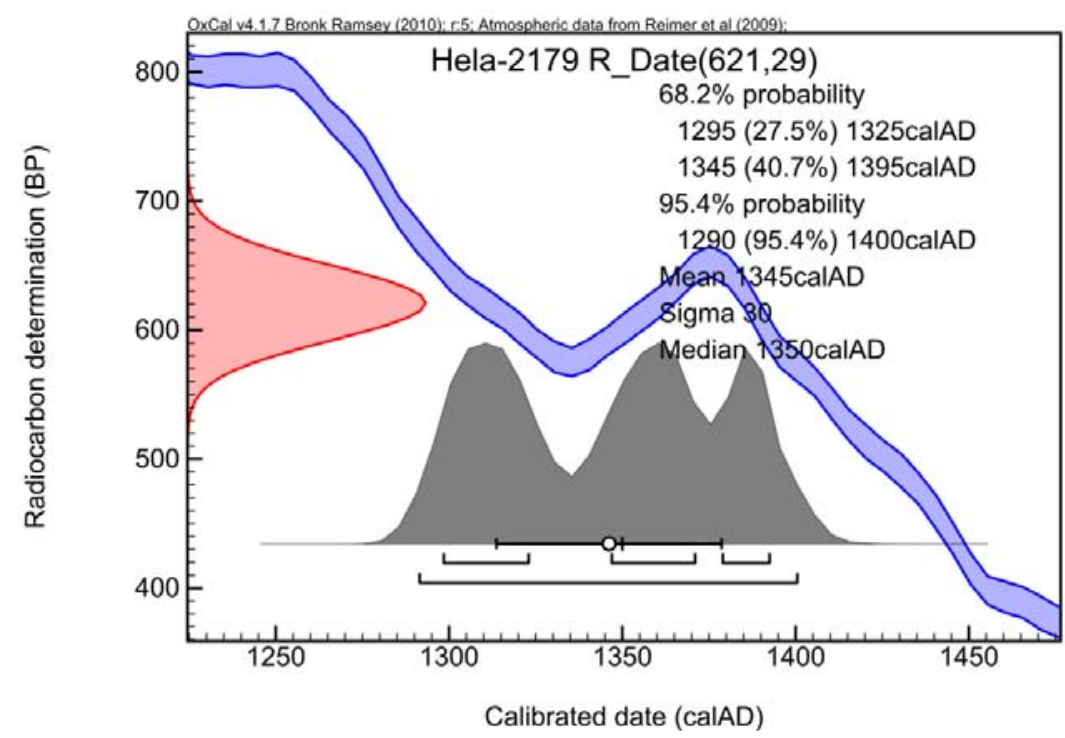

Figure 1 A typical ${ }^{14} \mathrm{C}$ date calibration of a 14th century find. The posterior calendar year probability distribution spreads to a $>100$-yr period of time due to changes of the atmospheric ${ }^{14} \mathrm{C}$ concentration.

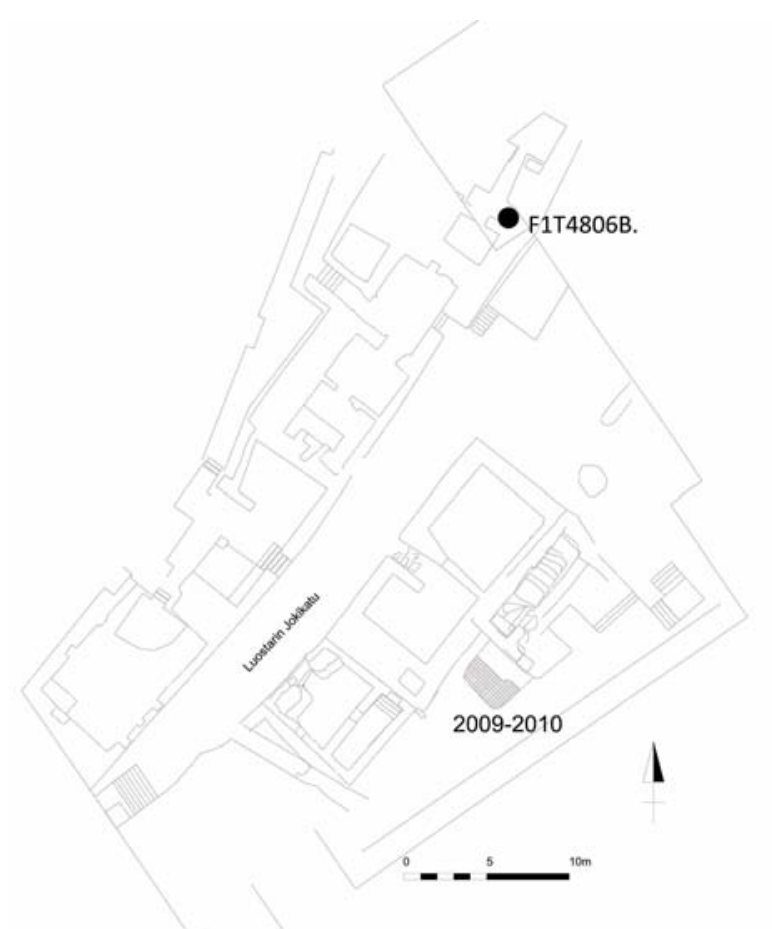

Figure 2 Schematic layout of Aboa Vetus Museum. The excavated (2009-2010) area is marked in gray. The location of the log F1T4806B used in the wiggle-match exercise is marked with a black dot. 


\section{Bayesian Model Dating for Medieval Turku}

excavations at the Aboa Vetus Museum. The approach ultimately yielded a Bayesian model date covering the early phases of urbanization in Finland. This study forms the foundation for a broader utilization of Bayesian model dating within eastern Fennoscandian archaeology.

\section{METHODS}

The timing of the early phases of the development of Turku, and the Aboa Vetus in particular, has been based mainly on archaeological material (mainly pottery) and dendrochronological work. According to archaeological excavations, the oldest structures may have been situated along the banks of the Aura River. The Aboa Vetus Museum displays one such population center and in this work one of its house yards was investigated (e.g. Hiekkanen 2002; Pihlman 2010; Seppänen 2011 and 2012; Taavitsainen and Uotila 2009 and references therein).

\section{Archaeology}

Archaeological excavations at the Aboa Vetus during the 1990s left some of the museum area untouched. This was a part of a yard paved with stones and it stood out from its surroundings as a $1.5-\mathrm{m}$-high and $10-\mathrm{m}^{2}$ structure. After the work in the 1990s, this structure was protected from all sides with a cover made of concrete. In the 2009-2010 archaeological excavations, the covered structure was revisited and $6 \mathrm{~m}^{2}$ of it was excavated. Being an elevated structure, it was possible to approach it sideways from a southwesterly direction. Therefore, the approach allowed for careful recording of its stratigraphic units. The progress was documented with tachymetry, photogrammetry, and laser scanning (LiDAR) techniques. The methodology ensured that the stratigraphic units remained unmixed during the work. The excavations yielded a large amount of datable material and a priori information to be included to dating model. A multitude of archaeological layers was observed on top of an empty clay layer, with a gradual increase of archaeological material, which illustrated the start of urbanization on the bank of the Aura River.

At the excavation site, the observed archaeological layers were located on top of a seemingly undisturbed and clean clay layer (1127, see Figure 3). On top of this, there was a set of localized and colored patches of soil (1143) that were interpreted possibly as signatures of agricultural land use. This was considered as an initial phase of human influence at the site. A dirty clay layer (1116) without any archaeological finds was present almost throughout the excavated site. The first direct human influence was observed within layer 1124 on top of this dirty clay layer. In particular, many wooden chips were found illustrating the beginning of construction works at the site (phase 2). Layers of organic humus, wood chips, and humus mixed with clay $(1123,1125)$ were covering this phase of first direct human influence and were considered to form phase 3. Pieces of wood were also found from these layers, but these could not be described as structures. A pit (1141) penetrated through layers 1123, 1125, and partly even 1116 and was filled with a humus-rich soil (1139) containing a large amount of animal bones. On top of the pit, there were 2 wood-chip layers $(1131,1130)$ separated by a clay layer reflecting another 2 construction phases. Based on these observations, the ordering of layers $1124>1125 \& 1123>1139>1131>1130$ was deduced to correspond to the assumed phases $2-6$.

A massive amount of datable material was found from these particular layers consisting of wood chips, decayed wood, pieces of animal skin, nutshells, seeds, and bones. Well-preserved wooden objects containing more than 50 tree rings were scarce. Of particular interest, no wooden samples were discovered with well-preserved outer tree rings under the phloem and bark layers. 


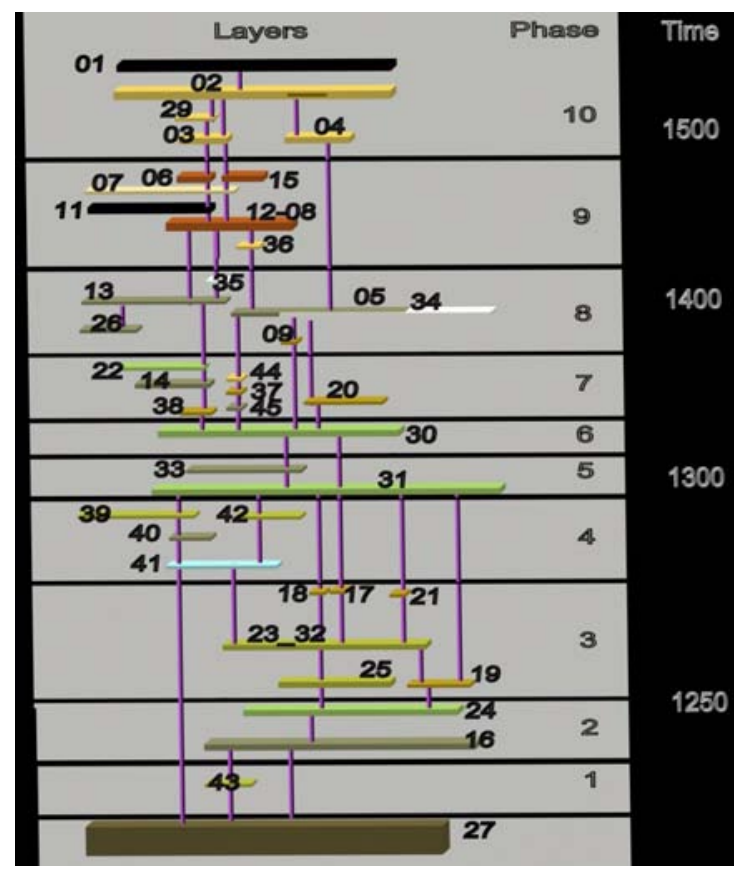

Figure 3 Observed archaeological layers with the coding used in this work. For convenience, the coding in the figure refers to the last 2 digits of the original coding used throughout the text $(27=1127$, etc $)$.

\section{Dendrochronology}

Owing to the lack of wood samples containing outer rings, the role of dendrochronology was fairly limited in our study. In particular, it was not possible to include dendrochronological dates reliably into the eventual dating model. However, they played a role in scrutinizing the wiggle-matching methodology for Aboa Vetus (Oinonen et al. 2012a,b and this work) and in establishing a terminus post quem estimate to compare with the model dating results (Zetterberg 2012).

The log F1T4806B was found in earlier excavations (2008) from the vicinity of the excavated area. We decided to use it as a reference sample in the wiggle-match methodology test. The log was dendrochronologically analyzed in the Laboratory of Dendrochronology at the University of Eastern Finland. The species was identified as Scotch pine (Pinus sylvestris L.). The ring widths were measured with a Kutschenreiter Digitalpositiometer-microscope from 2 different radii with a precision of $10 \mu \mathrm{m}$. The 2 series were averaged in order to form the final tree-curve F1T4806B. For the statistical properties for this series, see Table 1. The tree-curve dating was based on statistical and visual comparisons with other previously dated pine tree-ring material (1400 tree curves from SW Finland) and mean ring-width chronologies for the calendar year period AD 1012-1998.

Table 1 Dendrochronological data on the Aboa Vetus samples used in this work.

\begin{tabular}{|c|c|c|c|c|c|c|c|c|}
\hline Sample ID & Construction & $\begin{array}{l}\mathrm{Nr} \\
\text { of } \\
\text { rings }\end{array}$ & $\begin{array}{l}\text { Mean } \\
\text { width } \\
\mathrm{mm} / 100\end{array}$ & $\begin{array}{l}\text { Stand. } \\
\text { dev. }\end{array}$ & $\begin{array}{l}\text { 1-st order } \\
\text { autocorr. }\end{array}$ & $\begin{array}{l}\text { Mean } \\
\text { sensitivity }\end{array}$ & $\begin{array}{l}\text { Calendar } \\
\text { years }\end{array}$ & $\begin{array}{l}\text { Felling } \\
\text { date }\end{array}$ \\
\hline F1T4806B & R851 & 112 & 107.7 & 41.2 & 0.689 & 0.224 & 1276-1387 & $\begin{array}{l}\text { Winter } \\
1389 / 1390\end{array}$ \\
\hline F1T4807X & AV10, K1131 & 87 & 118.5 & 47.3 & 0.803 & 0.224 & $1178-1257$ & $>1257$ \\
\hline
\end{tabular}




\section{Bayesian Model Dating for Medieval Turku}

\section{Radiocarbon Methodology}

For the wiggle-match verification, tree rings from the F1T4806B log were chosen to cover the challenging period of the 14th century (Figure 1). The second half of the tree rings was suspected to be more decayed compared to material closer to the pith. Therefore, wood samples representing $1 \mathrm{yr}$ were cut at intervals of $10 \mathrm{yr}$ from the period AD 1318-1388, and the years 1373 and 1383 to ensure successful cellulose extraction from the last half. The cutting was made with a scalpel and razor blades under a microscope and the samples were cut into small slices.

Concerning the model dating, only samples of short-lived material were selected consisting of nutshells, animal skin, and the bones of young animals. Altogether, 12 individual ${ }^{14} \mathrm{C}$ analyses were performed within 5 assumed archaeological phases (2-6, Figure 3). The pretreatment of the samples was as follows.

\section{Wood}

Wood samples were acid-washed ( $2 \mathrm{hr}$ ) with $2 \% \mathrm{HCl}$ at $80^{\circ} \mathrm{C}$ to remove possible carbonate contaminants. After neutralization, organic acids were removed from the samples by performing a hot $\left(80^{\circ} \mathrm{C}\right)$ wash in $2 \% \mathrm{NaOH}(30 \mathrm{~min})$ twice. The samples were again neutralized and placed in a hot $\left(80^{\circ} \mathrm{C}\right.$ ) solution of distilled $\mathrm{H}_{2} \mathrm{O}+\mathrm{HCl}+\mathrm{NaClO}_{2}$. The solution was refreshed until the residual cellulose was completely bleached. The cellulose samples were then acid-washed again at $80^{\circ} \mathrm{C}$ until completely white cellulose was obtained to ensure the total removal of the $\mathrm{NaClO}_{2}$. All the samples were then neutralized with distilled water, centrifuged, and dried at $90{ }^{\circ} \mathrm{C}$ overnight.

\section{Bone}

Bone collagen was extracted by using the modified Longin method (Longin 1971). The bone sample was first mechanically and ultrasonically cleaned in distilled water. It was then dried at $100{ }^{\circ} \mathrm{C}$ overnight, ground to 0.5 - to $1-\mathrm{mm}$ grains on which hydrolysis and the removal of carbonate contaminants were performed with $10 \% \mathrm{HCl}$ at $5{ }^{\circ} \mathrm{C}$ temperature. After neutralization, humic acids were removed from the sample by leaching the insoluble residue at room temperature with $0.5 \% \mathrm{NaOH}$ for $18-20 \mathrm{hr}$. The solution was again neutralized and the sample placed in distilled water with $\mathrm{pH}$ adjusted to $2-3$ by adding $\mathrm{HCl}$. This was left at $90^{\circ} \mathrm{C}$ for $24 \mathrm{hr}$ with continuous mixing. This process formed a soluble gelatin from which insoluble humic acids were separated by a centrifuge. The remaining soluble gelatin was then dried for packing and combustion.

\section{Skin and Nutshells}

The pretreatment procedure followed the typical acid-alkali-acid (AAA) treatment. In other words, the first 2 steps were the same as for the wood samples, but the cellulose extraction was replaced by an additional acid-washing (2 hr) with $2 \% \mathrm{HCl}$ at $80^{\circ} \mathrm{C}$.

Pretreated samples were mixed with a stoichiometric excess of $\mathrm{CuO}$ and packed into glass ampoules, which were pumped to form a vacuum and torch-sealed. The packed samples were combusted at $520^{\circ} \mathrm{C}$ overnight. The released $\mathrm{CO}_{2}$ was collected and purified with liquid $\mathrm{N}_{2}$ and ethanol traps at -196 and $-85^{\circ} \mathrm{C}$, respectively. After purifying and measuring the sample $\delta^{13} \mathrm{C}$ value with IRMS (Finnigan MAT Delta-E), the $\mathrm{CO}_{2}$ samples were converted to graphite targets in the presence of a zinc powder and iron catalyst (Slota et al. 1986). Accelerator mass spectrometry (AMS) measurements were performed at the Uppsala Tandem Laboratory. 


\section{Oinonen et al.}

\section{CHRONOLOGICAL MODELS}

The chronological analyses on Aboa Vetus were conducted using the OxCal v 4.1 software (Bronk Ramsey 2009a) and the IntCal09 calibration curve (Reimer et al. 2009). All the analyzed results and phase boundaries (Boundary option in OxCal) have been given by using the 68\% highest posterior density (HPD) regions. We use the concept outlier analysis (Bronk Ramsey 2009b) to assess the quality of the chronological models, supported by agreement indices (Bronk Ramsey 1995, 2009a). For outliers, we have adopted the General model with the basic settings recommended in Bronk Ramsey (2009b).

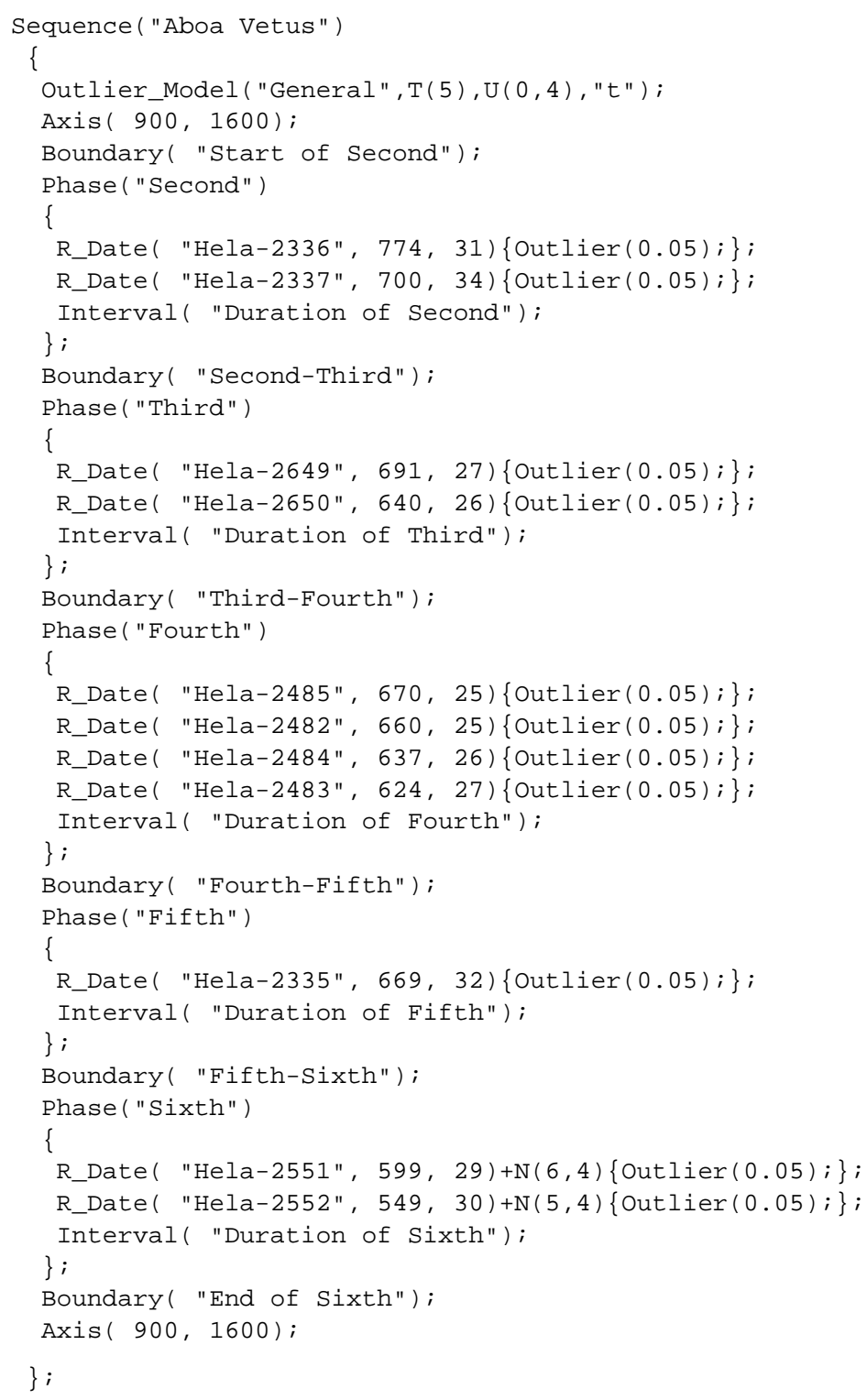

Figure 4 Chronological model assuming successive phases 2-6 


\section{Bayesian Model Dating for Medieval Turku}

The wiggle-match model took into account the ordering and time separation of wood samples from the $\log$ F1T4806B. The starting point for the analyses was $\mathrm{N}=10$ individual dates. If the combined agreement index was below a certain threshold value $\left(A_{\text {comb }}<A_{n}\right)$, the date having the lowest individual agreement index $\left(\mathrm{A}_{\mathrm{i}}\right)$ was omitted and the model was run again with $\mathrm{N}=\mathrm{N}-1$. This was continued until $\mathrm{N}=2$. The quality of a wiggle-match model is estimated by assessing the outlier probabilities and agreement indices for the models with $\mathrm{N}=2-10$.

The typical set of ${ }^{14} \mathrm{C}$ analyses is a compromise between the precision and accuracy required, and the budget available. Therefore, the quality of the results of all possible 2-sample pairs within the 10 performed tree-ring analyses was also estimated to see how well such 2-sample pairs could reproduce the known felling year. To obtain that, both 1-sample analyses and 2-sample wiggle-match analyses were performed applying the known time distance from the samples to the felling year.

The final model for the archaeological excavation assuming 5 successive phases is given in Figure 4 . Values for bone sample ages were estimated to be $6 \pm 4$ (Hela-2551) and $5 \pm 4$ yr (Hela-2552) based on osteological analyses. These were taken into account in the model as corresponding normal distributions shifting the dates to younger direction. We estimate the quality of the final model based on outlier analysis and by comparing its agreement index $\mathrm{A}_{\text {model }}$ with a threshold of $60 \%$ (Bronk Ramsey 2009a).

\section{RESULTS AND DISCUSSION}

\section{Dendrochronology}

Based on dendrochronological dating, there are annual rings from AD 1276 to 1389 in the sample F1T4806B. The annual rings for AD 1388-1389 were deformed due to decay and are not included in the tree curve (Table 1). The precise felling date could be traced to the winter season 1389/1390. Thus, the felling of the tree happened after the end of the growing season August-September in 1389 and before the beginning of the growing season May-June 1390 (Zetterberg 2008).

\section{Wiggle-Matching Based on Individual Dates}

The results of the individual ${ }^{14} \mathrm{C}$ dates for wiggle-matching are shown in Table 2. These fall within the range 506-721 BP and result in broad individual posterior calendar year probability distributions, as expected. The wiggle-match results are given in Figure 5 by plotting the accuracy (systematical uncertainty as difference between the modeled mean and the true felling year), precision (statistical uncertainty as $68 \%$ HPD of the posterior distribution), and posterior outlier probability of the most outlying date $\left(\mathrm{P}_{\text {largest }}\right)$ as a function of $\mathrm{N}$.

After including all the dates into the model $(\mathrm{N}=10), 1$ date (Hela-2172) is a significant outlier with a probability of $39 \%$. This also corresponds to the lowest combined agreement index within $\mathrm{N}=2$ 10. However, the software downweighs the outlying date and nearly perfect accuracy and reasonable precision $(9 \mathrm{cal} \mathrm{yr})$ is obtained. Removal of this outlier $(\mathrm{N}=9)$, or any other date suppressing the combined agreement index below the threshold $A_{n}(N=7,8)$, cannot essentially improve the result further. In fact, the precision and accuracy remain similar down to $\mathrm{N}=3$ and all wiggle-match results $(N=2-10)$ clearly surpass the single date result $(N=1)$, as expected.

If assuming $A_{\text {comb }}>A_{n}$ as an acceptance criterion, the optimal accuracy ( $+3 \mathrm{cal}$ yr), precision (11 cal yr), and model quality ( $A_{\text {comb }}=92 \%$ ) is obtained with 4 dates and this results in the 68\% HPD range of cal AD 1387-1398. This is better by a factor of 10 compared to the typical result of an individual ${ }^{14} \mathrm{C}$ date (Figure 1 ). 
M Oinonen et al.
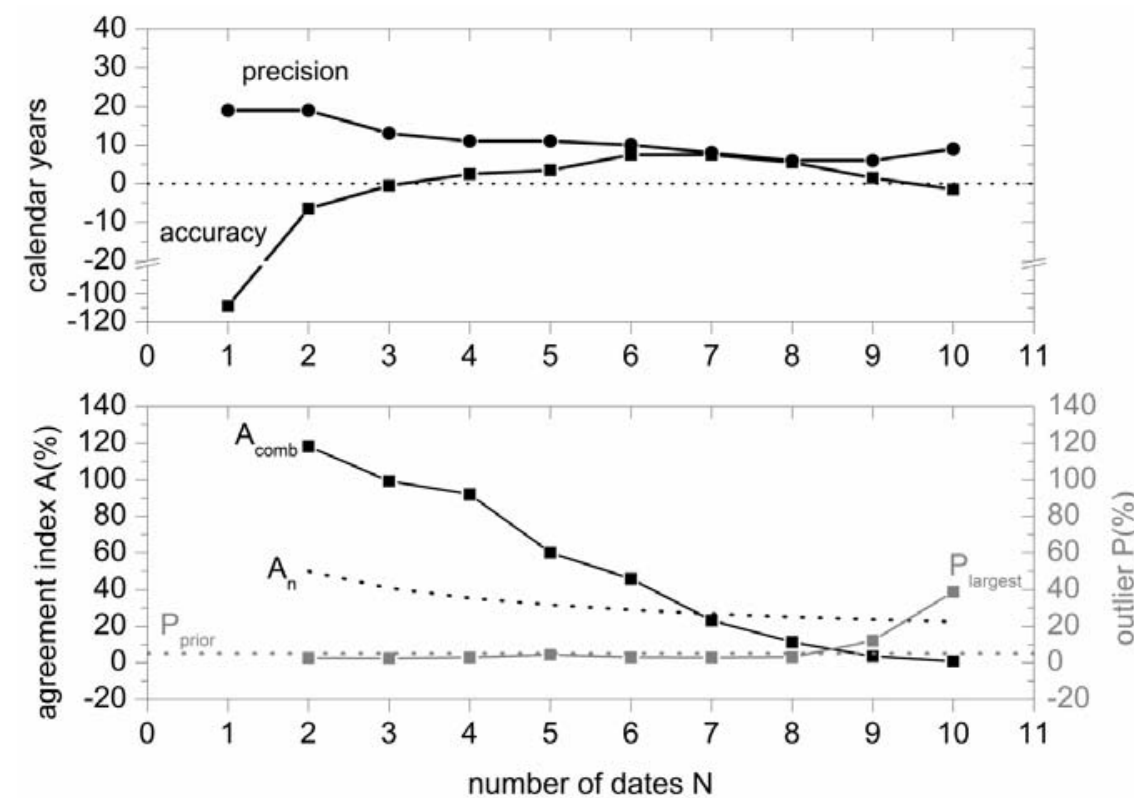

Figure 5 The results of the wiggle-match excercise are given by lines with closed symbols. The reference values (e.g. $P_{\text {prior }}=5 \%$ for outliers, Bronk Ramsey 2009b) are given as dotted lines.

Table 2 Individual ${ }^{14} \mathrm{C}$ dates for the basis of the wiggle-matching scrutiny of Aboa Vetus context.

\begin{tabular}{llll}
\hline Lab nr & Sample & $\delta^{13} \mathrm{C}(\%)$ & ${ }^{14} \mathrm{C}$ age $(\mathrm{BP})$ \\
\hline Hela-2179 & Wood, AD 1318 & -23.6 & $621 \pm 29$ \\
Hela-2178 & Wood, AD 1328 & -24.9 & $506 \pm 31$ \\
Hela-2177 & Wood, AD 1338 & -24.4 & $640 \pm 31$ \\
Hela-2176 & Wood, AD 1348 & -24.3 & $632 \pm 30$ \\
Hela-2175 & Wood, AD 1358 & -24.3 & $691 \pm 30$ \\
Hela-2174 & Wood, AD 1368 & -23.7 & $678 \pm 28$ \\
Hela-2180 & Wood, AD 1373 & -23.9 & $718 \pm 28$ \\
Hela-2173 & Wood, AD 1378 & -24.8 & $653 \pm 30$ \\
Hela-2181 & Wood, AD 1383 & -23.5 & $716 \pm 29$ \\
Hela-2172 & Wood, AD 1388 & -23.7 & $721 \pm 26$ \\
\hline
\end{tabular}

The results of the 1-sample analyses and the 2-pair wiggle-match models are given in Figure 6a to illustrate the power of a moderate increase in number of ${ }^{14} \mathrm{C}$ analyses. The narrowest $68 \% \mathrm{HPD}$ region for the felling date of 2-sample pairs covering the true felling date is $11 \mathrm{cal} \mathrm{yr} \mathrm{(cal} \mathrm{AD} \mathrm{1387-}$ 1398). This can be compared to the best result of the 1-sample analyses, which is a factor of 8 worse (cal AD 1336-1430). Based on the posterior probabilities of Figure 6b, the corresponding improvement is nearly 5 -fold. On average, the $68 \%$ ranges are 46 and $103 \mathrm{cal}$ yr for the 2 - and 1 -sample analyses, respectively, leading to a better than 2-fold improvement. Consistently, the average posterior probabilities indicate 3 times better results for the 2-sample analyses. Whereas the quality improvement seems evident with 2 samples analyzed, the success of such 2-sample wiggle-matching naturally depends on the interplay between the sample selection and the calibration curve, as illustrated by half of the analysis results in Figure 6 having large systematical and statistical uncertainties. 
a) $68 \%$ HPD ranges

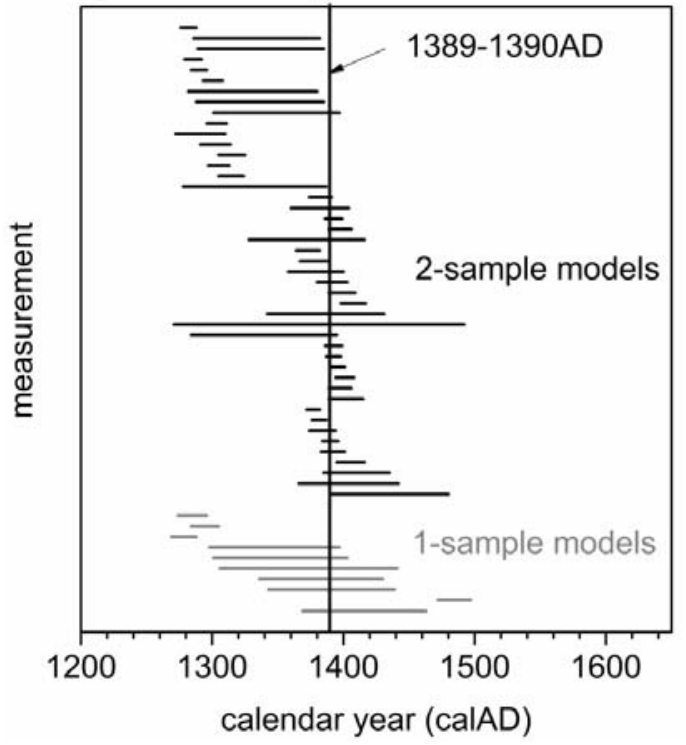

b) $\mathrm{P}$ for $1389-1390 \mathrm{AD}$

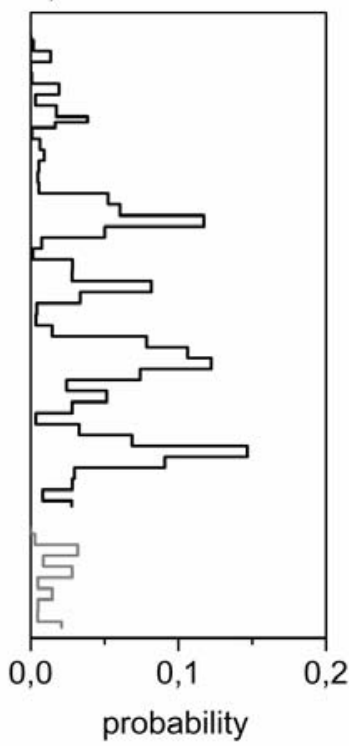

Figure 6 Results of 1-sample analyses, 2-sample wiggle-match analyses, and comparison to the known felling year. The results are given as (a) 68\% HPD ranges and (b) summed posterior probabilities of the years cal AD 1389-1390.

\section{Early Phases of Urbanization Displayed at Aboa Vetus}

Individual samples and dates on unknown samples are listed in Table 3. Nutshell, animal bones, and pieces of skin all yielded dates consistently from the 13th-14th centuries. Thus, an individual date would reflect a very broad calendar year probability distribution, as discussed above. Initial model analyses with all the dates involved indicated 1 date (Hela-2334) causing the agreement index to fall slightly below the threshold $\left(\mathrm{A}_{\text {model }}=49.1 \%\right)$. In addition, the date was considered as an outlier with a slightly elevated probability of $\mathrm{P}_{\text {outlier, Hela-2334 }}=15 \%$. Although this date did not significantly affect the final results, it was nevertheless omitted from the final dating model to respect the agreement index criterion of $>60 \%$. Eventually, the final model yields in the agreement index of $\mathrm{A}_{\text {model }}=$ $95.5 \%$, which is clearly above the acceptance threshold.

Table 3 Individual ${ }^{14} \mathrm{C}$ dates of the $2009-2010$ archaeological excavations at Aboa Vetus.

\begin{tabular}{lllll}
\hline Lab $\mathrm{nr}$ & Sample & Layer & $\delta^{13} \mathrm{C}(\%)$ & ${ }^{14} \mathrm{C}$ age $(\mathrm{BP})$ \\
\hline Hela-2336 & Nutshell & 2 & -26.8 & $774 \pm 31$ \\
Hela-2337 & Nutshell & 2 & -25.7 & $700 \pm 34$ \\
Hela-2649 & Nutshell & 3 & -23.9 & $691 \pm 27$ \\
Hela-2650 & Nutshell & 3 & -25.2 & $640 \pm 26$ \\
Hela-2485 & Skin & 4 & -25.7 & $670 \pm 25$ \\
Hela-2482 & Nutshell & 4 & -24.1 & $660 \pm 25$ \\
Hela-2484 & Skin & 4 & -26.1 & $637 \pm 26$ \\
Hela-2483 & Nutshell & 4 & -24.2 & $624 \pm 27$ \\
Hela-2334 & Nutshell & 5 & -25.3 & $727 \pm 31$ \\
Hela-2335 & Nutshell & 5 & -24.7 & $669 \pm 32$ \\
Hela-2551 & Bone (cattle) & 6 & -21.9 & $599 \pm 29$ \\
Hela-2552 & Bone (sheep) & 6 & -21.6 & $549 \pm 30$ \\
\hline
\end{tabular}




\section{Oinonen et al.}

The results of the final chronological model (Figure 4) are shown in Figure 7 and Table 4. Both 68\% and 95\% HPD regions are provided in Table 4 together with mean values. We discuss the model results later on, according to the 68\% HPD values. As expected, including the stratigraphical order into the model as a priori information removes impossible calendar years from the probability distributions and thus makes the posterior calendar year distributions narrower. The century-wide individual distributions are typically reduced so as to be decades wide.

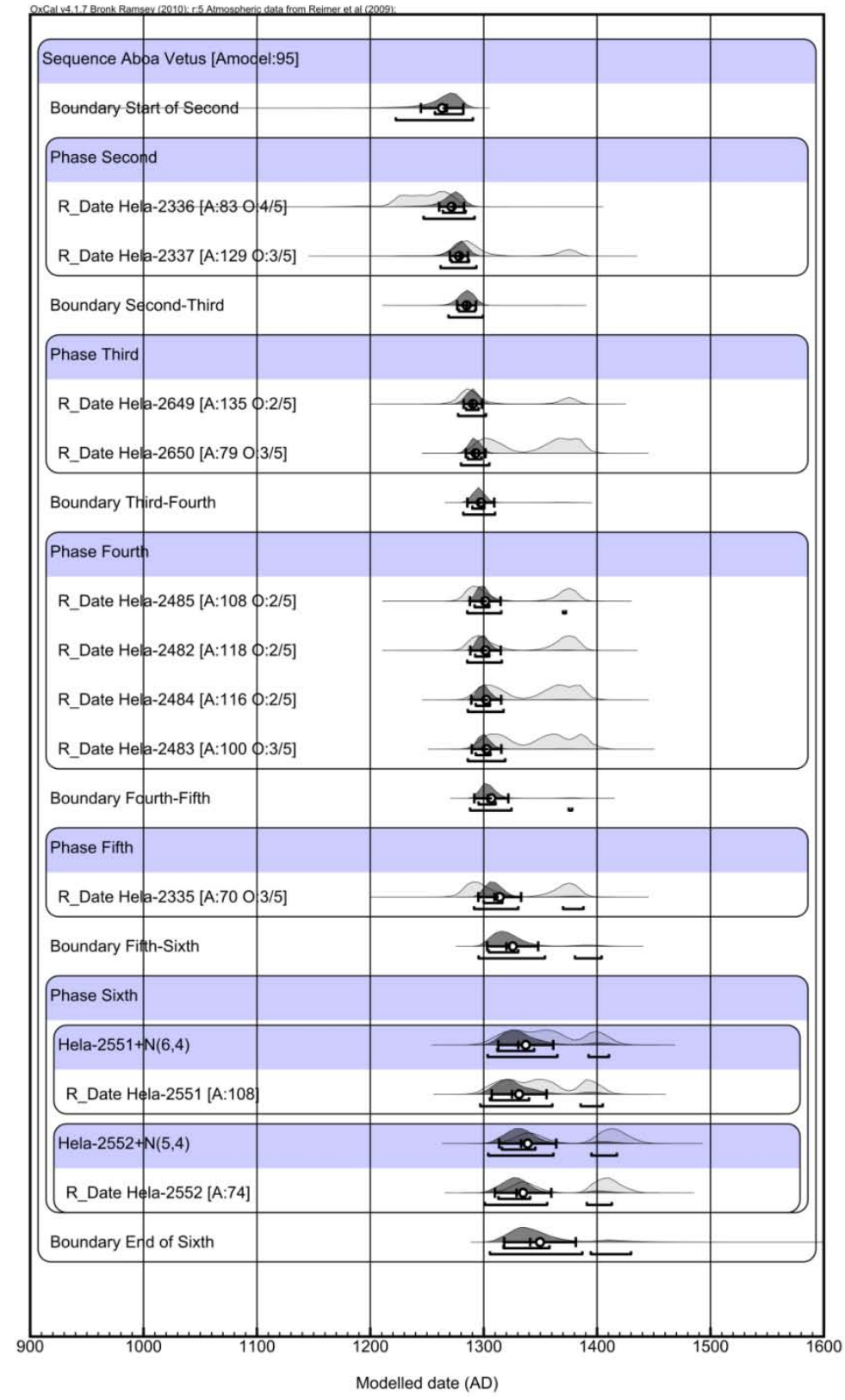

Figure 7 Results of the chronological model of the Aboa Vetus excavations 


\section{Bayesian Model Dating for Medieval Turku}

According to the model dating, the second phase and thus the earliest clear human influence starts during the second half of the 13th century (cal AD 1256-1281) and continues until the last quarter (cal AD 1278-1292). The phase is characterized by small amounts of wood chips indicating the start of construction work on the river bank. The following phase 3 with signs of human occupancy (layers of organic humus, wood chips, a piece of wood) seems to last more than a decade and ends on the eve of a new century (cal AD 1290-1300). The pit filled with various organic material from the phase 4 indicates a trash dump covering the early 14th century (end boundary at cal AD 12951310). The clearly distinct phases 5 and 6 seem to reflect the first decades of a more pronounced human occupation of the area.

Table 4 Results of the chronological model of Figure 4. Both boundaries (in cal AD) and interval lengths (in yr) have been given.

\begin{tabular}{|c|c|c|c|c|}
\hline Phase & $\begin{array}{l}\text { Years cal AD } \\
(68 \%)\end{array}$ & $\begin{array}{l}\text { Years cal AD } \\
(95 \%)\end{array}$ & $\begin{array}{l}\text { Mean } \pm \text { stdev } \\
(\text { cal AD) }\end{array}$ & Phase characteristics \\
\hline Second Start & $1256-1281$ & $1220-1290$ & $1262 \pm 22$ & \\
\hline Duration of Second & $0-27$ & $0-64$ & $22 \pm 24$ & $\begin{array}{l}\text { layer } 1124 \text {, wood chips, start of con- } \\
\text { structions }\end{array}$ \\
\hline Second - Third Boundary & 1278-1292 & 1268-1299 & $1284 \pm 9$ & \\
\hline Duration of Third & 0-16 & 0-33 & $13 \pm 14$ & $\begin{array}{l}\text { layers } 1125,1123 \text {, organic humus + } \\
\text { clay }\end{array}$ \\
\hline Third - Fourth Boundary & $1290-1300$ & $1281-1311$ & $1298 \pm 13$ & \\
\hline Duration of Fourth & 0-13 & $0-27$ & $9 \pm 10$ & $\begin{array}{l}\text { layer } 1139 \text {, a pit with a humus-rich } \\
\text { soil, animal bones }\end{array}$ \\
\hline Fourth - Fifth Boundary & 1295-1310 & 1288-1379 & $1307 \pm 16$ & \\
\hline Duration of Fifth & $0-24$ & $0-57$ & $19 \pm 18$ & $\begin{array}{l}\text { layer } 1131 \text {, wood chips, log } \\
\text { F1T4807X, construction phase }\end{array}$ \\
\hline Fifth - Sixth Boundary & 1304-1331 & 1295-1404 & $1326 \pm 23$ & \\
\hline Duration of Sixth & 0-30 & $0-74$ & $24 \pm 24$ & $\begin{array}{l}\text { layer } 1130 \text {, wood chips, construc- } \\
\text { tion phase }\end{array}$ \\
\hline Sixth End & 1318-1358 & 1306-1431 & $1350 \pm 32$ & \\
\hline
\end{tabular}

The obtained chronology agrees well with the typological dating of the phases based on pottery/ stoneware of mostly German origin (Pihlman 2012). In particular, in phases 5 and 6 pottery from the beginning of the 14th century starts to appear frequently. Moreover, the obtained datings are also in accord with the glassware typology (Haggren 2012).

Dendrochronological cross-matching between new material and the material studied and dated earlier provides additional support for the chronology (Zetterberg 2012). The only dendrochronologically datable new piece of wood for the context of this study (sample F1T4807X, see Table 1) was found in layer 1131 (phase 5). However, the piece could not be considered to form a clear structure. Although the piece of wood was strongly decayed, 87 tree rings could still be identified. The last observable tree ring was growing in AD 1257. Thus, only a terminus post quem estimate could be obtained for the felling year of the tree as $>1257$ (Zetterberg 2012). Our chronological model estimates that phase 5 flourished in the first 3 decades of the 14th century. It is possible that a wooden object of this kind could have been in use during those decades.

The ${ }^{14} \mathrm{C}$ dating of mortar has begun to contribute to studies of Finnish Medieval archaeological contexts (Heinemeier et al. 2011; Lindroos et al. 2012 and references therein). The 14th century wide calendar year probability distributions due to the ${ }^{14} \mathrm{C}$ calibration curve also persist for this approach. The quantitative treatment of the dates of various sample types within the same dating model should also allow for the suppression of the uncertainties induced by the curve for mortar dating. With active outlier analysis, this may even help to improve the intrinsic quality of mortar dating methodology. 


\section{Oinonen et al.}

The studies of the eve of urbanization in Finland have long been challenging due to the fragmentary and ambiguous nature of the historical sources. Furthermore, questions have arisen concerning the nature of the earliest settlements and the corresponding strata. Excavations that reach the earliest layers are technically challenging and often the lowest layers are adversely affected or even destroyed by the excavation work. In this study, we have demonstrated the power of combining careful excavations, stratigraphical recording, ${ }^{14} \mathrm{C}$ analyses, and implementation of the obtained information into Bayesian dating models. This study can be considered a landmark effort in terms of combining multidisciplinary methodologies for future studies of archaeological sites in Finland from planning to implementation.

\section{CONCLUSIONS}

The wiggle-matching methodology from sample pretreatment to model analysis has been tested within the Aboa Vetus Museum site of Turku, Finland. The analyses have been extended to model dating with a Bayesian inference to study early phases of the town of Turku on the bank of the Aura River. The results of the dating model agree with the typological dates of the archaeological finds and illustrate the evolution of urbanization in one of the oldest cities in Finland.

For Finnish archaeological research, the wiggle-match and model chronologies that have been established are pioneering in nature. This forms the foundation to increase the awareness of the possibility to include archaeological a priori information in analyses of the past. Other potential sites where wiggle-matching methodology and stratigraphical information could be used include, for instance, other Medieval towns, churches, castles, and hillforts. Overall, it is expected that, and supported by increasing awareness, the usage of ${ }^{14} \mathrm{C}$ dates and dating will evolve from single analyses to more comprehensive approaches.

\section{ACKNOWLEDGMENTS}

The authors want to thank Mrs Anne-Maija Forss for ${ }^{14} \mathrm{C}$ sample treatment, Mr Igor Shevchuk for IRMS measurements, Mrs Auli Bläuer (born Tourunen) for osteological analyses and bone age estimations, and Ms Mia Lempiäinen for analyzing the plant remains. The project was funded by the Finnish Cultural Foundation.

\section{REFERENCES}

Bronk Ramsey C. 1995. Radiocarbon calibration and analysis of stratigraphy: the OxCal program. Radiocarbon 37(2):425-30.

Bronk Ramsey C. 2009a. Bayesian analysis of radiocarbon dates. Radiocarbon 51(1):337-60.

Bronk Ramsey C. 2009b. Dealing with outliers and offsets in radiocarbon dating. Radiocarbon 51(3):102345.

Bronk Ramsey C, van der Plicht J, Weninger B. 2001. 'Wiggle matching' radiocarbon dates. Radiocarbon 43(2A):381-9.

Christen JA, Litton CD. 1995. A Bayesian approach to wiggle-matching. Journal of Archaeological Science 22(6):719-25.

Haggren G. 2012. Lasipikareita ja ikkunansirpaleita Aboa Vetuksen alueen uudet löydöt ja Turun varhaisvaiheet. SKAS 4:50-6.

Heinemeier J, Ringbom Å, Lindroos A, Sveinbjörnsdót- tir ÁE. 2010. Successful AMS ${ }^{14} \mathrm{C}$ dating of non-hydraulic lime mortars from the Medieval churches of the Åland Islands, Finland. Radiocarbon 52(1):171-204.

Hiekkanen M. 2002. Die Gründung der Stadt Turku. Civitas et castrum ad Mare Balticum, Baltijas arheoloijas un vstures problmas dzelzs laikmet un viduslaikos. Rakstu krjums - veltjums LZA stenajam loceklim prof. Dr. habil. hist. Andrim Caunem 65 gadu dzves jubilej. Latvijas vstures institta apgds. Riga. p 156-77.

Lindroos A, Regev L, Oinonen M, Ringbom Å, Heinemeier J. 2012. ${ }^{14} \mathrm{C}$ dating of fire-damaged mortars from Medieval Finland. Radiocarbon 54(3-4):91531.

Longin R. 1971. New method of collagen extraction for radiocarbon dating. Nature 230(5291):241-2.

Oinonen M, Hilasvuori E, Nordqvist H, Uotila K, Zetterberg P. 2012a. Context dating of medieval Turku wiggle matching technique scrutinized at Aboa Vetus. 


\section{Bayesian Model Dating for Medieval Turku}

Castella Maris Baltici X (2009). In: Uotila K, Mikkola T, Vilkuna A-M, editors. Archaeologica Medii Aevi Finlandiae XVIII. Saarijärvi. p 191-6.

Oinonen M, Hilasvuori E, Nordqvist H, Uotila K, Zetterberg P. 2012b. Turun kaupungistumisen alkuhetkien radiohiiliajoituksia bayesilaisella menetelmällä. SKAS 4:15-26.

Pearson GW. 1986. Precise calendrical dating of known growth-period samples using a "curve fitting" technique. Radiocarbon 28(2A):292-9.

Pihlman A. 2010. Turun kaupungin muodostuminen ja kaupunkiasutuksen laajeneminen 1300-luvulla. In: Söderstöm M, editor. Varhainen Turku. Turun museokeskuksen raportteja 22. p 79-94.

Pihlman A. 2012. Aboa Vetus \& Ars Nova museon tontin vv. 2009-2010 laivausten saviastiat 1200-luvun jälkipuoliskolla ja 1300-luvun alkupuolella. SKAS 4: 43-9.

Reimer PJ, Baillie MGL, Bard E, Bayliss A, Beck JW, Blackwell PG, Bronk Ramsey C, Buck CE, Burr GS, Edwards RL, Friedrich M, Grootes PM, Guilderson TP, Hajdas I, Heaton T, Hogg AG, Hughen KA, Kaiser KF, Kromer B, McCormac FG, Manning SW, Reimer RW, Richards DA, Southon JR, Talamo S, Turney CSM, van der Plicht J, Weyhenmeyer CE. 2009. IntCal09 and Marine09 radiocarbon age calibration curves, 0-50,000 years cal BP. Radiocarbon 51(4): $1111-50$.

Sartes M. 2003. Rettigin palatsin tontista tuli Aboa Vetus -museo. Kaupunkia pintaa syvemmältä. In: Seppänen L, editor. Arkeologisia näkökulmia Turun historiaan. AMAF IX. p 77-86.
Seppänen L. 2011. Lost but found underground. Construction, development and maintenance of medieval streets and squares of Turku (Finland). In: Proceedings of the 16th International Conference on Cultural Heritage and New Technologies. Vienna, Austria 2011. p 476-90.

Seppänen L. 2012. Rakentaminen ja kaupunkitilan käyttö keskiajan Turussa - Eritystarkastelussa Åbo Akademin päärakennuksen tontin arkeologinen aineisto [PhD thesis]. University of Turku.

Slota Jr PJ, Jull AJT, Linick TW, Toolin LJ. 1986. Preparation of small samples for ${ }^{14} \mathrm{C}$ accelerator targets by catalytic reduction of CO. Radiocarbon 29(2):303-6.

Taavitsainen J-P, Uotila K. 2009. Recent urban archaeological work in Finland with particular reference to the towns of Turku/Åbo and Naantali/Nådendal in Finland Proper. The Hansa town Riga as mediator between East and West. Andris Caune and Ieva Ose. Riga. p 58-67.

Uotila K. 2009. Aboa Vetus. In: Muhonen T, LehtoVahtera J, editors. Rauniokohde ja sen tutkimus. Ikuinen raunio. $p$ 42-63.

Zetterberg P. 2008. Turun Aboa Vetus \& Ars Nova -museon vuoden 2008 arkeologisen kaivauksen puunäytteen dendrokronologinen ajoitus, näyte F1T4806. Joensuun yliopisto, Biotieteiden tiedekunta, Ekologian tutkimusinstituutti, Dendrokronologian laboratorio, ajoitusseloste 335. p 1-4.

Zetterberg P. 2012. Dendrokronologisten näytteiden ristiinvertailulla uusia ajoitustuloksia Aboa Vetus-museon vanhoista näytteistä. SKAS 4:27-31. 